\title{
III-treatment and torture in demonstrations and other non-custodial settings. How can academic research help in the discussion?
}

\author{
Pau Pérez-Sales, MD, PhD, Psych*, Editor in Chief
}

The events in October 2017 in Catalonia exemplify the difficulty of establishing what 'excessive use of force' means. ${ }^{1}$ Images of violent repression of defenceless people of all ages waiting to vote accompany the Spanish government's spokeswoman reiterating in the media that what the police force is doing is "proportional" and therefore allegedly acceptable. Can scientific research add to the debate on what is "proportional" and when an intervention in non-custodial settings enters into what is banned under the Convention against Torture and Other Cruel, Inhuman or Degrading Treatment or Punishment ('CAT')? This is not a minor issue. According to international databases, from an epidemiological point of view, torture happens mainly in prisons and police stations linked to marginalised populations. Ill-treatment and torture against political dissidents and protesters is less frequent, but widespread, affecting around $70 \%$ of countries across the world (Conrad, Haglund, \& Moore, 2013)

The Special Rapporteur on Torture and Other Cruel, Inhuman or Degrading Treatment or Punishment (SRT) has recently made it clear that use of force can amount to torture. Any extra-custodial use of force that does not pursue a lawful purpose (legality), or that is unnecessary for the achievement of a lawful purpose (necessity), or that inflicts excessive harm compared to the purpose pursued (proportionality), amounts to cruel, inhuman or degrading treatment or punishment (CIDT). Additionally, if the person is powerless (that is, a person who is under direct physical or equivalent control and is unable to escape or resist), and the action is intended to inflict pain or suffering for a certain purpose, he considers that it will amount to torture irrespective of the above considerations of lawful purpose, necessity and proportionality (SRT, $2017 \mathrm{p}$ 23). This should be the standard of reference from now on.

Even the failure to take all precautions practically possible in the planning, preparation and conduct of law enforcement operations with a view to avoiding the unnecessary, excessive or otherwise unlawful use of force, contravenes the State's positive obligation to prevent acts of cruel, inhuman or degrading treatment or punishment within its jurisdiction (SRT, $2017 \mathrm{pp} 23$ ).

Until recently, International courts have always been reluctant to take this stance. The

\footnotetext{
*) SiR[a] Centre, GAC Community Action Group and Hospital La Paz, Spain.

Correspondence to: pauperez@arrakis.es
}
1 See for instance https://www.amnesty.org/en/ latest/news/2017/10/spain-excessive-use-of-force- by-national-police-and-civil-guard-in-catalonia/


SRT follows and consolidates the doctrine stated by the European Court of Human Rights (ECHR) in Cestaro v. Italy $2015^{2}$ and Bartesaghi Gallo and Others v. Italy 2017. ${ }^{3}$ In both these cases, the Court found that the violent punching, kicking and beating with rubber truncheons of anti-globalisation protestors in Genova in 2001 amounted to torture. In contrast, judgments emanating from the Inter-American Court of Human Rights have, at the very most, considered such actions and even more serious physical abuse as only amounting to CIDT. In Finca La Exacta vs Guatemala (ICHR, 2002), the court considered "disproportionate" an intervention on peasants who were on private, occupied land ${ }^{4}$ that ended with three persons shot dead. The long-awaited outcome of the case of the women of Atenco, admitted in September 2016, where 11 women claimed to have been sexually assaulted by the Mexican police after a demonstration and

2 The case involved a 62-year-old demonstrator, who was being compliant and surrendering, by an Italian police officer who beat him with a hand-held baton to the point where he suffered fractures and other injuries amounting to torture.

3 The Court noted that, although none of the victims showed violence or resistance, and although all of them were manifestly unarmed, asleep or sitting with their hands raised above their heads, the police systematically and indiscriminately subjected each of them to violent beatings, intentionally inflicting severe physical and psychological suffering for the purposes of retaliation and humiliation through the use of excessive, indiscriminate and manifestly disproportionate force.

4 A group of families occupied a landowner's property to protest over their salary and living conditions. The operation to detain three persons ordered by the local court involved 200 special agents with the use of tear gas and support by helicopters. It ended with three peasants dead and 11 severely beaten. The Court considered that the intervention was legitimate but disproportionate and amounted to CIDT. whether it will result in a finding of torture or CIDT is likely to be determinative for future similar cases. ${ }^{5}$ Furthermore, the UN Committee against Torture has also expressed concern over the excessive use of force by law enforcement officials during the policing of demonstrations or crowd control. ${ }^{6}$

Can medical and psychological research contribute anything to this legal debate on the excessive use of force and its relation to torture?

\section{Intentionality and purpose. Police brutality or police torture? Babovic} (2000) argues for the need to distinguish police brutality from police "torture." $\mathrm{He}$ claims that excessive use of force is often caused by the need - and potentially legal right - to "establish control" and that police officers often act improperly in anger, frustration or in fear of a real or imagined aggression. ${ }^{7}$ In such a case, there would not

5 There were clashes in 2002 in protests against the planned construction of a new international airport for Mexico City. In 2006, new clashes followed the expulsion of eight downtown flower vendors by the police from their traditional places in the local market. The latter confrontation marked the beginning of a series of demonstrations and riots, which lasted over a week and resulted in over 100 arrests and numerous allegations of human rights abuses committed by the police against the local population, including the detention of 40 women, 11 of whom claimed they were sexually assaulted while in detention and in transport to the police station.

6 For example, Concluding Observations of CAT: Canada, UN Doc. CAT/C/CAN/CO/6 (2012) $\$ 22.362$ Concluding Observations of CAT: Denmark, UN Doc. A/52/44 (1997) \$182; Sweden, UN Doc. A/52/44 (1997) \$222. Concluding Observations of CAT: Syria, UN Doc. CAT/C/SYR/ CO/1/Add.2 (2012) $\$ 20(j) .364$ Concluding Observations of CAT: UK, UN Doc. A/54/44 (1999) $\$ 76(\mathrm{~g}) .365$ Concluding Observations of CAT: Canada, UN Doc. CAT/C/CR/34/CAN (2005) §4(i); Canada, UN Doc. A/56/44 (2001) \$58(a).

7 This idea that torture and police brutality are dif- 
be a clear purpose according to the examples suggested by the Convention against Torture (UNCAT) definition and it therefore should not be considered as CIDT or torture, but as "excessive use of force." This position, quite popular in local and national courts to avoid sentencing police involved in violent actions in the repression of collective movements, is misleading for the following reasons: (a) purpose is a necessary requirement for torture, but not for CIDT. It is enough to credit severe mental or psychological suffering by State agents which are not part of a lawful sanction (Neziroglu, 2007); (b) studies show that an important percentage of use of force actions are linked to officers confronted with situations that challenge their identity (e.g., displays of citizen disrespect). These actions to "defend identity" can often equate to the purposes of humiliation or punishment included in the Convention (Felson \& Tedeschi, 1993); and, (c) selected jurisprudence and SRT reports have stressed the relevance of the criteria of "defencelessness" when analysing excessive use of force incidents. Defencelessness in itself might turn a CIDT situation into torture (Nowak \& McArthur, 2006; SRT, 2017)

\section{Torturing system. Repression of} dissidents. Additionally, although the definition in UNCAT arguably focuses

ferent things is reflected in the use of what could be considered euphemistic language. For instance, the Manual on Use of force and Detainee Injury Reporting of the Detroit Police Department labels Serious Use of Force to "Any action by an officer that involves: 1) The use of deadly force, including all critical firearm discharges; 2) A use of force in which the person suffers serious bodily injury or requires hospital admission; 3) A canine bite; and 4) The use of chemical spray against a restrained person." All of them actions that for an external observer could perfectly be considered as potentially amounting to ill-treatment or torture (DPD, 2012). on the interaction between one person (tormenting agent) and another (tortured person), torture has an undeniable social dimension. In its extreme form, torture is a social institution of power and dominance; it is part of a torturing system that designs, plans, hides and guarantees immunity and it uses victims to threaten and demobilise every layer of society. According to this sociological model, the purpose of violent actions in assemblies, demonstrations, protests and other non-custodial collective settings are demobilisation, fear, control and submission of the individual and the collective. There surely can be a purpose in police brutality that is covered by the examples given by the Convention.

Interestingly enough, political science has studied since the 1970's the relationship between state repression and social mobilisation. ${ }^{8}$ The available data show that there is not a linear relationship between repression and demobilisation. In a review of studies, Davenport (2007) finds what he calls the "Punishment Puzzle": sometimes the impact of repression on dissent is negative, sometimes it is positive, sometimes it is represented by an inverted U-shape, sometimes it is dynamic and alternates between negative or positive and sometimes it is nonexistent. We still do not have a clear map of key variables that help to explain the consequences of political repression on social and political movements.

8 State repression is defined in political science as the actual or threatened use of physical sanctions against an individual or organization, within the territorial jurisdiction of the state, for the purpose of imposing a cost on the target as well as deterring specific activities and/or beliefs perceived to be challenging to government personnel, practices or institutions. CIDT and torture are among the most severe forms of state repression (Davenport, 2007). 
Measuring use of force in citizen encounters. Use of force is difficult to demarcate and observe. It can be broadly defined as any situation where, in the execution of their duty, police use verbal or physical force or other techniques, including a weapon, instrument or implement to respond to an actual or perceived threat (Hine, Porter, Westera, \& Alpert, 2016).

There have been several attempts to measure it for academic research. Alpert and Dunham (1997) developed the Relative Force Factor Model (RFFM) to measure the proportionate use of force by control agents. In the model, both officer's force and level of suspicion of resistance is measured in a continuum. The relative force factor score is calculated by subtracting the suspect's highest level of resistance to the force used by police. Terrill, Alpert, Dunham, \& Smith (2003) refined this model in the RCFS (Resistance Force Comparative Schema) model. The RCFS model tries to define proportionality not as a static variable (the maximum level of force used by actors in a certain encounter), but in a dynamic way by which a comparison is made at different time points. ${ }^{9}$ For example, if a police officer uses pepper spray on a calm person, this is likely to provoke an aggressive reaction in the person and bystanders may react, which may in turn lead to the police using maximum force, physically threatening the bystanders and beating and handcuffing the originally calm person. The RFFM model, based on its maximum measure, would set out that such a reaction is a proportionate

9 By using this dynamic measure, the immediacy criteria, a fundamental criteria in some penal codes, would be included: If a threat to police has not yet materialised, a forcible response is too early and constitutes pre-emptive force; if the threat has passed, a forcible response is retaliation. intervention, as the detainee used physical resistance and the police answered with pain compliance. The RCFS measure would split the interaction in a sequence of events, measure proportionality in each moment of the sequence and obtain an overall score of whether the intervention was proportionate.

Using this dynamic model, Paoline and Terrill (2011) raise different scenarios of resistance of a citizen (verbal resistance, passive physical resistance, non-assaultive physical reaction (i.e. going away; hiding parts of their body to avoid arrest), and assaultive physical reaction). They analyse the response considered appropriate by the police in a coercive escalation (verbal threats, verbal commands and threats, pain compliance techniques (e.g., pressure point control), soft empty-hand techniques (e.g., grabbing, shoving), hard empty-hand techniques (e.g., striking with fists), chemical-irritant sprays (e.g., oleoresin capsicum), electronic devices (e.g., TASER gun), baton, and projectile launchers (e.g., beanbag)). In a research study with a sample of more than 1000 police officers from different areas of the US, they found that most of the respondents self-declared very conservative responses (zero to negative values in RCFS measures), although between $5 \%$ to $10 \%$ of police officers depending on geographical area, reported escalating to forms of maximum aggressiveness in the face of comparatively minor events (scores of +2 to +6 ) without the authors being able to define a clear sociodemographic pattern of the "high risk" policemen. ${ }^{10}$ Academic research clearly points

10 Klahm \& Tillyer (2010) reviewed all available research on use of force published in peer-reviewed journals between 1995 and 2008. Most of the variables used throughout the literature seem to have a mixed relationship with or appear to be poor predictors of use of force by police. For 
Table 1 Resistance/force continuum and Resistance Force Comparative Scheme (RFCS)

Resistance/force continuum

Levels of suspect resistance

1: No resistance

2: Passive

3: Verbal

4: Defensive

5: Active
Levels of police force

1: No force

2: Command

3: Threat

4: Restraint and control

5: Pain compliance/takedown

6: Impact

Resistance Force Comparative Scheme (RFCS)

\begin{tabular}{|c|c|c|c|}
\hline \multirow[b]{2}{*}{ Suspect resistance } & \\
\hline & Less force & Commensurate force & More force \\
\hline 1 & - & 1,2 & $3,4,5,6$ \\
\hline 2 & 1 & 2,3 & $4,5,6$ \\
\hline 3 & 1,2 & 3,4 & 5,6 \\
\hline 4 & $1,2,3$ & 4,5 & 6 \\
\hline 5 & $1,2,3,4$ & 5,6 & - \\
\hline
\end{tabular}

Source: Terrill, Alpert, Dunham, \& Smith (2003)

out the need for clear regulations in all kind of scenarios and for political decisions on accountability in cases of abuse.

Research using the relative force model is just beginning and has relied mostly on samples from the US and Australia (Hine et al., 2016). It is promising not only as a measurement tool for force (Hickman, Atherley, Lowery, \& Alpert, 2015) but also as a tool for policing agencies to identify

example, analysis of available evidence regarding officer experience and use of force shows that in some studies more experienced police were less likely to de-escalate, in others more experienced police recommended using less physical violence while some studies suggest that more experienced police were simply less investigated by internal affairs. 'high at risk' officers (Bazley, Mieczkowski, \& Lersch, 2009).

In a summary of available studies on violent interactions, results point to that police officers tend to use more physical violence when (a) the offence is perceived as more serious, (b) when they perceive the suspect to have less authority than themselves, (c) the subject is verbally but not physically aggressive, (d) a greater number of officers are involved in the situation, and, (e) the policemen have extra resources available to control the subject. Police officers are less likely to resort to physical violence (a) if the person is exceedingly resistant, (b) looks fit, (c) the officer perceives environmental risks, (d) bystanders are present (Alpert, 2004; Bolger, 2015; Terrill, 2005; Weisburd, Greenspan, \& Hamilton, 2000). 
We need more refined and ecological models, which take into account the fact that police behaviour is not only based on personal characteristics but also on a constellation of factors ranging from patterns of encounters and personal experiences to community, political and work contexts. Stewart (2013) has tried to build such a model by measuring use of force through a scale that takes into account what he calls circumstantial evidences: information that the police had previous to the intervention, characteristics of the citizen involved (age, mental health status etc), measures of threat that the citizen poses against himself or others, severity of the alleged offence etc. The result is the Constitutional Force Analysis Tool (CFA) a very complex integrative measure of use of force by state agents. Although this is a very comprehensive tool, the data are so specific that it can only be carried out through an administrative self-report done by the agents after an intervention.

It seems logical to assume that a report that can have legally and administratively adverse consequences for the security agents involved probably is a poor source of reliable information. In CFA, no contrast with witnesses, other officers or the alleged victims is carried out. In relation to that, one of the black holes in academic research are estimates of the reliability of police reports of incidents. Klinger \& Brunson (2009) offer some preliminary studies on a high frequency of perceptual distortions potentially leading to erroneous decisions and erroneous reporting during critical incidents. But as these same authors recognise "police officers have been known simply to lie" (Klinger \& Brunson, 2009 p 135) to protect themselves. The extent of such lying is also one of the great unknowns within the policing world. A reliable measure of inaccuracy of police declarations in excessive use of force incidents would be of great help for an overall picture of the problem.

Bad apples or bad orders. A balanced use of force may well be the norm in non-custodial interventions, especially in democratic countries (Harris, 2009). The idea that typically only a small number of officers account for a disproportionate percentage of the total number of complaints of use of excessive or unnecessary force was already suggested by the General Force Research, a multicentre US study in the 1990's (Adams, 1996) and has consistently been confirmed since (William Terrill \& Ingram, 2016).

These data do not however show whether there are simply always a number of "bad apples" in any given group, or whether there is a small trained group of officers (quite often not publicly recognised and recognisable) that is "allowed" to use excessive force and subsequently protected, or there is a lack of adequate control of violent units. Available academic data seems to give more support to this latter systemic hypothesis. Terril (2005) analysed 3,340 use of force incidents from three US agencies with the focus on policy direction and restrictiveness. The results show that officers working within the most restrictive policy framework used force less readily than officers who operated within more permissive policy environments. Data suggest it is a problem of environment and orders, not of bad apples. Chappel and Lanza (2009) used an anthropological observational methodology in a US police academy and found out that despite the philosophical emphasis on community policing and its themes of decentralisation and flexibility, the most salient lessons learned in police training were those that reinforced the paramilitary structure and culture. 
Non-lethal weapons. The debate on excessive use of force as CIDT or torture is necessarily linked to the debate on the use of the so-called non-lethal weapons. Interestingly, in Terrill and Paoline's study (2012) police officers considered the use of chemical and electronic weapons at very early stages in a process of escalation of conflict, before physical force. This shows the widespread idea that these weapons are a legitimate way of avoiding violence, while in fact they are a very violent way to solve a conflict.

Amnesty International (AI) (2015) has recently produced a manual that endorses the use of the so-called less-lethal weapons to control riots and public demonstrations (chemical irritants, sound devices, electric shock devices (either projectiles or stun batons), kinect impact weapons (and special rubber balls and pellet firing shot guns) and water cannons). Amnesty's position is that, if properly regulated, their use is an advantage over conventional firearms. Having different types of devices to confront a threat, in their view, would minimise the use of firearms and suggests they must be available as a standard for law enforcement agencies. The AI report is focused on the legal perspectives and does not develop in-depth social, medical or psychological considerations, where arguably the debate on CIDT/torture should. Even the expression less-lethal weapons recognises the fact that no technology can be guaranteed to be non-lethal. They are weapons that are sold as having low risk of permanent injury or death, as if this were the only relevant criteria.

The truth is that besides being humiliating, some of them are considered extremely dangerous, and that the available epidemiological evidence shows that their use entails a higher risk of injury to citizens than traditional use of force (Crowley, 2016; Haar, Iacopino, Ranadive, Weiser, \&
Dandu, 2017) due to at least four reasons: (a) it is very difficult to respect instructions of use amidst the chaos of an intervention (i.e. minimum distance at which a human being can be shot safely with a rubber ball); (b) some of them constitute collective punishments as it is almost impossible to act selectively and bystanders, third persons or even demonstrators who are trying to help in keeping an action as a non-violent movement will be equally affected; (c) there are always especially vulnerable populations (i.e citizens with cardiac vulnerabilities, asthma or others); (d) it is very difficult to control abusive use (i.e. using electric shots in a defenceless person as a punishment). The use of body-worn cameras solves some but not of all these problems.

Additionally, some of these implements (especially electric-shock devices) can be used as torture tools in the interrogation of detainees and their availability in countries where no control can be guaranteed is a real risk.

\section{The necessity and legitimacy criteria. Reasons for using force against} citizens. Felson \& Tedeschi (1993) defined from a set of interviews with police officers three reasons for use of force against citizens: (1) to establish control of a situation; (2) to desire to achieve or restore justice according to an assessment of blameworthiness; (3) for self-presentation or "to establish or to protect identities." 11 According to this classification, only control situations would

11 This concern for self- presentation is even greater in the presence of third parties. Officers are socialised to "maintain the edge" and be "one up" on citizens not only to establish control, but to ensure proper respect. As a result, officers confronted with situations that challenge their identity (e.g., displays of citizen disrespect) may be countered by a more forceful response. 
Table 2: Less-lethal weapons as related to CIDT and torture

\begin{tabular}{ll}
\hline Humiliating or Degrading & - Malodorant water cannon \\
\hline $\begin{array}{l}\text { Highly likely that third persons } \\
\text { or bystanders are affected }\end{array}$ & - Pellet firing shot guns \\
\hline
\end{tabular}

Likely that vulnerable citizens might be badly damaged

- Gas and chemical irritants (asthma, hyper sensibility to components). Deaths have been reported

- Electric devices (cardiac patients). Deaths have been reported

- Sonic weapons (sonic bullets, cannons etc). Damage to internal organs, hearing loss, eye damage. Deaths have been reported

Highly likely that instructions of use regulations cannot be followed in a stressful situation eventually provoking severe damage or lethal consequences
- Rubber coated metal bullets (eye loss / brain concussions, kidney damage)

- Water cannons (eye loss, head concussion)
Highly likely facilitating CIDT/ Torture by the level of suffering inflicted
- Electric shock devices that do not have a cut-off point

- Electric gun that acts as a direct contact weapon

- Thumb-cuffs

- $\quad$ Spiked batons, extendible defences

- Whips

Inherently considered CIDT/

- Body-worn electric shock belts

Torture

Source: Re-working of information included in AI (2015).

allow for force to be legitimate, while achieving justice and establishing identity should be considered as an unlawful use of force.

Since disrespectful behaviour should not form the basis for a legal response, while resistance does, some countries have legislated to consider "disrespect" as legally punishable. If the measure of excessive use of force and the measure of resistance are complex, the measure of "disrespect" is simply impossible, opening a space for arbitrary actions from police. Even more concerning and objectionable is the fact that in some national penal codes offences linked to Disrespect or Resistance to Authority have severe penalties including sometimes measures of deprivation of liberty, the purpose of which is too often to deter social activists. This can also lead to police charging on these grounds to avoid accusations of excessive force particularly when, in the absence of witnesses or video-recordings, the police version of the encounter always prevails.

From the citizen's point of view. Protests entail many emotions in participants. There are at least three objects of emotion: the opponent, the in-group, and contentious 
issues. Protesters are likely to experience negative emotions towards their opponent and the contentious issue, while they most likely feel positive emotions towards the group they identify with. The analysis of individual and collective emotions during protest have shown a direct relationship between police actions, collective positive or negative emotions and escalation of conflict potentially leading to violence (Troost, Stekelenburg, \& Klandermans, 2013). ${ }^{12}$

Using data from the UK, where there are strong supervision mechanisms, Smith (2009) found out that only $7 \%$ of citizens suffering police misconduct filed a complaint (and an additional $6 \%$ tried unsuccessfully and gave up), while less than $5 \%$ of these complaints where substantiated after investigation. In a review of US studies Terrill and Ingram (2016) showed that only between 0 and $12 \%$ of complaints against police use of excessive use of force were later sustained by investigative bodies when the case was considered by an internal process of the police.

According to the UK data, the main reason $(62 \%)$ for those who did not complain was finding it a useless action. This was not far from reality as in those cases where the officer was found guilty, the research showed that this led to no more than a conversation with a supervisor or a minor administrative sanction. The second more frequent reason not to complain was that it took a lot of time and work. In other countries, it must be added that, as stated above, filing a complaint can have strong negative consequences for the person if she is counter-denounced by

12 This is why some scholars propose that any measure of excessive use of force should also include a scale of de-escalating of conflict to analyse tactics used by police to prevent use of violence (Stewart, 2013). disrespect or resistance to authority.

Additional ways to discourage or discredit citizen allegations of excessive use of force is to detain the person, which also presents the police with an occasion to negotiate with the potential complainant and suggest not to bring charges if a legal claim is not already made (Smith, 2009) or to inform through the media only of violent intentions or behaviours in demonstrators creating a social climate of fear and a social narrative prone to social rejection of demonstrators and justification of ill-treatment (Bolshia, Gautier, \& Flores, 2016).

Additionally, participation in social movements is a stressful event in itself (Lau et al., 2017; Matthies-Boon, 2017) and suffering police violence can be an extremely disturbing experience. In the short-term, acute stress disorders, posttraumatic stress disorder (PTSD) and depression are common among victims (Unuvar et al., 2017) with in some cases a shattering of one's assumptive world in the long term (Matthies-Boon, 2017) precluding legal actions in the initial weeks after the clash, when the legal claim must be done. Psychosocial and psycho-legal accompaniment might help in this case, although non-governmental organisations also face the risk of being stigmatised or prosecuted (INCLO, 2013). Finally, sometimes complainants lack support-and are even accused of deserving prosecutionfrom relatives or friends due to it being a free choice to participate in a social and political action when knowing the risks potentially involved. However, more research is necessary.

More studies are needed generally on the physical and mental suffering caused by police violence in non-custodial settings and more particularly, research is clearly needed to document cases of potential 
CIDT or torture.

Who controls the controllers? The jurisprudence of the European Court of Human Rights (ECHR) uses the terms 'hierarchical and institutional' and 'practical' independence (or 'organisational' and 'functional' independence) when CIDT and torture claims are investigated in a national system. Claims that are investigated by a nonpolice institution are not necessarily done in an independent way. Even if the process goes beyond administrative assessment, it is not an exception that police officers and local courts work together cooperatively on a day-to-day basis. We only have preliminary data and also need more studies on systems of independence indicators that allow for an organisational analysis of different schemas of complaints (Smith, 2009). Nonindependence of review procedures has led to some favourable judgments of the ECHR related to excessive use of force (e.g., Ramsahai v The Netherlands, 2007).

A series of studies compared whether there were differences in the number of allegations of citizens depending on the investigative body. Overall, if allegations were investigated by commanding officers, the odds of a positive outcome decreased by a $39 \%$. Success was only slightly better with allegations examined by either an internal affairs department or by an external civil committee (probably due to difficulties in overcoming pacts of silence). The best results were obtained by those administrations where internal research was overseen by an external committee, which increased the likelihood of the allegations being considered by $76 \%$. These research data might importantly illiminate how to adequately deal with citizens' complaints to guarantee fair consideration of allegations of the use of force (Terrill \& Ingram, 2016).

A good example of how accountability can decrease CIDT and torture at the hands of the police is found in Brazil. Police in the state of Rio de Janeiro killed more than 8,000 people living in favelas in the decade between 2005 and 2015. Human Rights Watch conducted in-depth interviews with more than 30 police officers, who attributed the excessive use of lethal force to a pervasive "culture of combat" and corruption within military police battalions (Human Rights Watch, 2016). In São Gonçalo, the state's second largest city, between 2008 and 2010, a judge, a prosecutor, and civil police officers made a concerted effort to address extrajudicial killings and filed charges against 107 military police officers - about 15 percent of the troops in the military police battalion in São Gonçalo-during that period. The number of police killings in the city subsequently dropped by $70 \%$. Some police officers had warned that this effort to promote accountability would impede police work and result in a rise in crime, but the number of robberies and overall homicides in São Gonçalo also declined. Progress came to a halt when the judge was murdered by some of the police officers who were facing prosecution. In the absence of accountability, the number of police killings climbed again and is now higher than in 2008 (Human Rights Watch, 2016).

\section{Media tolerance towards CIDT and} torture. Finally, qualitative content analysis research has also shown that uncritical newspaper coverage of police-perpetrated ill-treatment may reflect and promote public and official tolerance for police violence (Gamal, 2017; Hirschfield \& Simon, 2010)

Conclusion. In summary, the academic world provides very interesting and largely unknown data relevant to the debate on CIDT and torture in non-custodial settings. 
Surely more data is necessary to confirm and expand what has been reflected upon here. Especially relevant would be studies on criteria for assessing necessity, legitimacy and proportionality, elements that foster police misconduct and ways to prevent it using ecological models based on the interplay of the political, social, group, individual and interactive variables involved in these kind of situations.

The recent report of the Special Rapporteur underlines the fact that the medical and psychosocial field has much to offer the legal world in better defining these not uncommon cases. It also gives food for thought regarding the need to increase the use of science in courts e.g. moving from a judge or internal review body deciding what is proportionate based on statements, to the potential use of more academic and evidencebased models assisting judges' decisions.

Repression is not a thing of the past. Carey (2006) has studied the dynamic relationship between protest and repression using data from six Latin American and three African countries from the late 1970s to the early 1990s. The results suggest that democracies were least likely to display continuous repressive behavior. However, if faced with popular dissent, democracies were just as likely to respond with coercion and negative sanctions as other regime types (restrictions on free speech, violations of life integrity rights, such as torture and political imprisonment, or other forms of state violence). In the end, repression has wide-reaching and negative consequences on society in terms of social control in that it can radicalise a minority, thus legitimise more violent actions and repression from the State and wide-spread political demobilisation of the majority due to fear.

\section{This issue}

This issue includes two papers that provide a more thorough understanding of the scientific basis for psychotherapeutic work with torture survivors, one of the priorities of the Journal (see editorial in issue 2017/1). This is especially important in certain contexts - like Africa - where very scarce information is available. We include the paper 'Towards a contextually appropriate framework to guide counseling of torture survivors in Sub-Saharan Africa' building on research carried out by Craig Higson-Smith and Gillian Eagle and 'Efficacy of evidence-based psychosocial model for the rehabilitation of torture suvrivors' by Domininique Dix-Peek and Merle Werbeloff from the South African Centre for Study of Violence and Reconciliation. Although not from the same geographical region, these studies are complemented by Karen Fondacaro and Emily Mazulla's paper on a proposed Chronic Traumatic Stress Framework.

Reparation and Transitional Justice is a topic rarely addressed in the Journal. Vera Vital-Brasil describes the Clinicas do Testemunho, a pilot project carried out in Rio de Janeiro, which was supported by the Amnesty Commission of the Brazilian Ministry of Justice. The paper gives food for thought regarding the connection between individual and collective healing in transitional justice processes. Laurence Kirmayer and James Jaranson contribute an essay on 'Cultural logics of emotion: Implications for understanding torture and its sequalae' that provides a useful and broad insight into the cultural meaning of emotions as linked to the experience of torture survivors.

The Debate in this issue concerns the APT-sponsored research (and book) Does torture prevention work? The book is an analysis of data collected from 13 countries regarding whether the implementation of the 
National Prevention Mechanisms (NPM) have been useful in the prevention of torture worldwide. Hans D. Petersen summarises the book and presents a critical paper questioning key aspects of the methodology and results. Carver and Handley, authors of the original book, respond, with a final right of reply given to the author of the paper.

\section{References}

Adams, K. (1996). Measuring the prevalence of police abuse of force. In W. A. Geller \& H. Toch (Eds.), Police violence: understanding and controlling police abuse of force (pp. 52-93). London: Yale Publications.

Alpert, G.P. and Dunham, R. G. (1997). The force factor: measuring police use of force relative to suspect resistance. Washington, DC:

Alpert, G. P. (2004). Interactive Police-Citizen Encounters that Result in Force. Police Quarterly, 7(4), 475-488. https://doi. org/10.1177/1098611103260507

Amnesty International. (2015). Use of force guidelines for implementation of the UN basic principles on the use of force and firearms by law enforcement officials. Amnesty International Netherland.

Babovic, B. (2000). Police brutality or police torture. Policing: An International fournal of Police Strategies \& Management, 23, 374-380. https:// doi.org/10.1108/13639510010343047

Bartesaghi Gallo and Others v. Italy (2017) European Court of Human Rights 12131/13 and 43390/13

Bazley, T. D., Mieczkowski, T., \& Lersch, K. M. (2009). Early intervention program criteria: Evaluating officer use of force. Fustice Quarterly, 26(1), 107-124. https://doi. org/10.1080/07418820801989742

Bolger, P. C. (2015). Just Following Orders: A MetaAnalysis of the Correlates of American Police Officer Use of Force Decisions. American fournal of Criminal Fustice, 40(3), 466-492. https://doi. org/10.1007/s12103-014-9278-y

Bolshia, E., Gautier, A., \& Flores, M. (2016). The work of ITEI in Sucre, Pando and Santa Cruz after the events of 2008 in Bolivia. In Delivering on the Promise of the Right to Rehabilitation Cumpliendo la Promesa del Derecho a la Rehabilitación. 4-9 December.Book of abstracts. Mexico: IRCT.

Carey, S. C. (2006). The Dynamic Relationship Between Protest and Repression. Political Research Quarterly, 59(1990), 1-11. https://doi. org/10.1177/106591290605900101

Cestaro v. Italy (2015) European Court of Human
Rights 6884/11

Chappell, A. T., \& Lanza-Kaduce, L. (2009). Police Academy Socialization: Understanding the Lessons Learned in a Paramilitary-Bureaucratic Organization. Fournal of Contemporary Ethnography, 39(2), 187-214. https://doi. org/10.1177/0891241609342230

Conrad, C. R., Haglund, J., \& Moore, W. H. (2013). Disaggregating torture allegations: Introducing the ill-treatment and torture (ITT) countryyear data. International Studies Perspectives, 14(2), 199-220. https://doi.org/10.1111/j.15283585.2012.00471.x

Crowley, M. (2016). Chemical Control: Regulation of Incapacitating Chemical Agent Weapons, Riot Control Agents and their Means of Delivery. Palgrave MacMillan.

Davenport, C. (2007). State Repression and Political Order. Annual Review of Political Science, 10(1), 1-23. https://doi.org/10.1146/annurev. polisci.10.101405.143216

DPD. (2012). Use of force and detainee injury reporting/ investigation. Directive 201.11.

Felson, R. B., \& Tedeschi, J. T. (1993). A social interactionist approach to violence: Cross-cultural applications. Violence and Victims, 8, 295-310.

Gamal, B. R. (2017). Impact of TV Terrorism News on Egyptians 'Perception of National Security Measures and Civil Liberties : A Cultivation Study A Thesis Submitted to the Department of Fournalism and Mass Communication In partial fulfillment of the requirements for the Mast.

Haar, R. J., Iacopino, V., Ranadive, N., Weiser, S. D., \& Dandu, M. (2017). Health impacts of chemical irritants used for crowd control: a systematic review of the injuries and deaths caused by tear gas and pepper spray. BMC Public Health, 17(1), 831. https://doi. org/10.1186/s12889-017-4814-6

Harris, C. J. (2009). Police Use of Improper Force: A Systematic Review of the Evidence. Victims $\mathcal{E}$ Offenders, 4(1), 25-41. https://doi. org/10.1080/15564880701568470

Hickman, M. J., Atherley, L. T., Lowery, P. G., \& Alpert, G. P. (2015). Reliability of the Force Factor Method in Police Use-of-Force Research. Police Quarterly, 18(4), 368-396. https://doi. org/10.1177/1098611115586175

Hine, K. A., Porter, L. E., Westera, N. J., \& Alpert, G. P. (2016). Too much or too little? Individual and situational predictors of police force relative to suspect resistance. Policing and Society, 0(0), 1-18. https://doi.org/10.1080/10439463.2016. 1232257

Hirschfield, P. J., \& Simon, D. (2010). Legitimating 
police violence: Newspaper narratives of deadly force. Theoretical Criminology, 14(2), 155-182. https://doi.org/10.1177/1362480609351545

Human Rights Watch. (2016). "Good Cops Are Afraid." ICHR. (2002). Informe No 57/02 [1]. Caso 11.382. Finca La Exacta vs Guatemala.

INCLO. (2013). "Take back the streets." Repression and criminalization of protest around the world. https:// tasz.hu/files/tasz/imce/full_report_-_english.pdf

Klahm, C., \& Tillyer, R. (2010). Understanding police use of force: a review of the evidence. Southwest Fournal of Criminal fustice, 7(2), 214-239.

Klinger, D. A., \& Brunson, R. K. (2009). Police officers' perceptual distortions during lethal force situations: Informing the reasonableness standard. Criminology \& Public Policy, 8(1), 117-140. https://doi.org/10.1111/j.17459133.2009.00537.x

Lau, J. T. F., Kim, Y., Wu, A. M. S., Wang, Z., Huang, B., \& Mo, P. K. H. (2017). The Occupy Central (Umbrella) movement and mental health distress in the Hong Kong general public: political movements and concerns as potential structural risk factors of population mental health. Social Psychiatry and Psychiatric Epidemiology, 52(5), 525536. https://doi.org/10.1007/s00127-017-1340-x

Matthies-Boon, V. (2017). Shattered worlds: political trauma amongst young activists in postrevolutionary Egypt. Fournal of North African Studies, 22(4), 620-644. https://doi.org/10.1080/1 3629387.2017.1295855

Neziroglu, I. (2007). A Comparative Analysis of Mental and Psychological Suffering as Torture, Inhuman or Degrading Treatment or Punishment under International Human Rights Treaty Law. Essex Human Rights Review, 4(1), 1-16.

Nowak, M., \& McArthur, E. (2006). The distinction between torture and cruel, inhuman or degrading treatment. Torture : Quarterly fournal on Rehabilitation of Torture Victims and Prevention of Torture, 16(3), 147-51.

Paoline, E. a., \& Terrill, W. (2011). Listen to me! Police officers' views of appropriate use of force. Fournal of Crime and Fustice, 34(3), 178-189. https://doi.org/10.1080/0735648X.2011.609740

Ramsahai v The Netherlands. (2007) European Court of Human Rights no. 52391/99

Smith, G. (2009). Why Don't More People Complain against the Police? European fournal of Criminology, 6(3), 249-266. https://doi. org/10.1177/1477370809102167

Special Rapporteur Against Torture. (2017). Extracustodial use of force and the prohibition of torture and other cruel, inhuman or degrading treatment or punishment (Vol. A/72/178).
Stewart, G. (2013). A Quantitative Method for the Analysis of Constitutional Factors in Police Use of Force. Porland State University.

Terrill, W. (2005). Police use of force: A transactional approach. Fustice Quarterly, 22(1), 107-138. https://doi.org/10.1080/0741882042000333663

Terrill, W., Alpert, G., Dunham, R. G., \& Smith, M. R. (2003). A Management Tool for Evaluating Police Use of Force: An Application of the Force Factor. Police Quarterly 2003, 6, 150. https://doi.org/10.1177/1098611103006002002 $10.1177 / 1098611102250491$

Terrill, W., \& Ingram, J. R. (2016). Citizen Complaints Against the Police. Police Quarterly, 19(2), 150-179. https://doi. org/10.1177/1098611115613320

Terrill, W., \& Paoline, E. A. (2012). Conducted Energy Devices (CEDs) and Citizen Injuries: The Shocking Empirical Reality. Fustice Quarterly, 29(2), 153-182. https://doi.org/10.1080/0741882 5.2010 .549834

Troost, D. Van, Stekelenburg, J., \& Klandermans, B. (2013). Emotions in protest. In Emotions in Politics: The Affect Dimension in Political Tension.

Unuvar, U., Yilmaz, D., Ozyildirim, I., Dokudan, E.Y., Korkmaz, C., Doğanoğlu, S., Kutlu, L., Fincanci, SK. (2017). Usage of Riot Control Agents and other methods resulting in physical and psychological injuries sustained during civil unrest in Turkey in 2013. Fournal of Forensic and Legal Medicine, 45, 47-52. https://doi. org/10.1016/j.jflm.2016.11.007

Viñar, M., \& Ulriksen, M. (1990). Fracturas de la Memoria. Cronicas de una memoria por venir. Montevideo: Trilce.

Weisburd, D., Greenspan, R., \& Hamilton, E. (2000). Police attitudes toward abuse of authority: Findings from a national study, 1-15. 